\title{
URIC ACID AS A FUTURE BIOMARKER IN DIAGNOSING METABOLIC SYNDROME PATIENTS.
}

\footnotetext{
1. MBBS, M.Phil

Assistant Professor Chemical

Pathology

Watim Medical and Dental College,

Rawat.

2. MBBS, MCPS, FCPS

Department of Pathology

Fazaia Medical College,

Air University, Islamabad.
}

Correspondence Address:

Dr. Shameela Majeed

Department of Chemical Pathology

Watim Medical and Dental College,

Rawat.

dr.shameela.m@gmail.com

Article received on:

29/01/2019

Accepted for publication:

$21 / 03 / 2019$

\begin{abstract}
Shameela Majeed ${ }^{1}$, Brig. Rizwan Hashim²
ABSTRACT... Background: To determine the possible correlation between raised serum uric acid and various components of metabolic syndrome (Waist circumference, serum triglyceride, plasma HDL-C). Study Design: Descriptive case control. Setting: Army Medical College laboratory, Military Hospital, Rawalpindi. Period: One year (November 2014 to October 2015). Material and Methods: Total of 100 subjects were enrolled in this study. WHO criteria were applied for identifying the patients of metabolic syndrome. Fasting plasma glucose, lipid profile and serum uric acid levels were measured by using colorimetric enzymatic method. The formula of Homeostasis Model Assessment-Insulin Resistance (HOMA-IR) was applied to calculate Insulin resistance. Collected data was analyzed by using SPSS- Window version-17 for statistical analysis. Results: Serum uric acid levels were turned out to be high in metabolic syndrome patients (cases $=6.1 \pm 1.3 \mathrm{mg} / \mathrm{dL}$ ) when compared with controls (having no symptoms of MetS $=3.6 \pm 1.2 ; \mathrm{p}<0.001$ ). Uric acid showed a statistically significant positive association with waist circumference $(\mathrm{WC}=\mathrm{r}$-value:0.250; $\mathrm{p}$-value:0.000) and serum triglyceride ( $T G=r$-value:0.341; $p$-value:0.000). Negative correlation had been found between plasma high-density lipoprotein-cholesterol $(\mathrm{HDL}-\mathrm{C}=\mathrm{r}$-value: -0.173 ; $p$-value: $<0.01)$ with uric acid levels. Conclusion: Serum uric acid levels show a significant association with components of metabolic syndrome making it a powerful biomarker of metabolic syndrome and its various cardiometabolic complications.
\end{abstract}

Key words: $\quad$ Cardiometabolic Metabolic Syndrome, Hyperuricemia, Type-2 DM.

Article Citation: Majeed S, Hashim R. Uric acid as a future biomarker in diagnosing metabolic syndrome patients. Professional Med J 2019; 26(11):1911-1915. DOI: 10.29309/TPMJ/2019.26.11.3191

\section{INTRODUCTION}

Uric acid (product of purine nucleosides degradation) plays a major role in protecting the erythrocyte membrane from lipid peroxidation as it destroys the free oxygen radicles. ${ }^{1}$ Apart from its antioxidant property of uric acid, its abnormal raised levels crystallize in joints resulting in gouty arthritis. ${ }^{2}$ Moreover, gout is also associated with various cardiometabolic diseases like hypertension, diabetes, CV diseases and metabolic syndrome. ${ }^{3}$ Increased prevalence of metabolic syndrome have been found in patients of hyperuricemia as compared to healthy population. ${ }^{4}$ Metabolic syndrome also known as "Syndrome-X" is a cluster of various abnormalities including abdominal obesity, arterial hypertension, increased risk of clotting, impaired fasting glucose and abnormal cholesterol levels. ${ }^{5,6}$ These physiological and anthropometric abnormalities occurring together in a metabolic syndrome patient are the major risk factor in developing chronic cardiometabolic diseases like stroke, diabetes mellitus and heart diseases. ${ }^{7,8}$ Moreover, the risk of developing cardiovascular diseases rises to 2-fold if serum of metabolic syndrome patients have raised uric acid levels. ${ }^{9}$ The hallmark of both metabolic syndrome and hyperuricemia is obesity, which is an epidemic of $21^{\text {st }}$ century. ${ }^{10}$ Apart from inflammatory cytokines like TNF-alpha and IL-6, increased adipose tissue also secretes several adipokines (leptin, adiponectin and resistin). Some of these, effects insulin sensitivity by acting on insulin signaling and molecules involved in glucose metabolism. ${ }^{11}$ These adipocytokines also impair the action of insulin on target organs, so body uses insulin less effectively than normal leading to insulin resistance. If insulin resistance 
persists, pancreases secrete more and more insulin in response with resulting compensatory hyperinsulinemia leading to glucose intolerance and type 2 diabetes. ${ }^{12}$ Considered as the rising disease of $21^{\text {st }}$ century and high prevalence of metabolic syndrome in gout patients, the present study has been designed to find the serum uric acid levels in metabolic syndrome and targets to establish the possible correlation between hyperuricemia and various components of metabolic syndrome.

\section{MATERIAL AND METHODS}

This research was carried out at Army Medical College, Rawalpindi in a time period of one year (November 2014 to October 2015) after getting permission from the Ethics Committee (institute also funded this research project). This case control study comprised of a sample size of 100 subjects (50 of each cases and controls) were enrolled from its affiliated Military Hospital laboratory (written consent of participant was also taken). Inclusion criteria was based on World Health Organization (WHO) criteria for metabolic syndrome in which all patients must have insulin resistance (IR) with 2 additional abnormalities:

1. BMI $>25 \mathrm{~kg} / \mathrm{m}^{2}$ or waist-hip ratio $>0.85$ in women and $>0.9$ in men.

2. High blood pressure $\geq 140 \mathrm{~mm} \mathrm{Hg}$ systolic or $\geq 90 \mathrm{~mm}$ Hg diastolic.

3. Serum Triglyceride $\geq 1.7 \mathrm{mmol} / \mathrm{l}$.

4. Serum HDL-cholesterol $<1.0$ in women and $<0.9$ in men.

The participants were excluded if they were taking lipid lowering, antihypertensive, antidiabetic, oral contraceptive (female) drugs or any medication that low the serum uric acid levels. Sociodemographic data was entered on a structured Performa along with the complete history of each participant. At the same time, anthropometric indices were measured: height (in $\mathrm{cm}$ with a standardized measuring chart), weight (in $\mathrm{kg}$ with a standardized scale without shoes) and blood pressure (mean of 2 readings at an interval of five minutes by sphygmomanometer). Body mass index (BMI) was calculated by the formula $=$ weight $(\mathrm{kg})$ / height (m2). For laboratory analysis, $12 \mathrm{ml}$ of overnight fasting (atleast 12 hour) venous blood sample was collected under sterile conditions and equal amounts were transferred to a plain vacutainer for serum analysis and EDTA tube for plasma analysis (participants were advised to take a preferably vegetable diet in previous three days). After centrifugation for 15 minutes at 2200-2500 RPM (revolution per minute), routine investigations were done on the same day while the serum was stored at -20 ${ }^{\circ} \mathrm{C}$, until the analysis of insulin. Plasma glucose, serum uric acid, serum triglyceride (TG), plasma high density cholesterol (HDL-c) were estimated on fully automated chemistry analyzer -Selectra-E (controls were run with each run) by the enzymatic colorimetric method (Globe diagnostic kits). Serum insulin was measured by solid phase, enzyme labeled chemiluminescent immunometric assay on Access-2 immunoassay-Beckman Coulter (Siemens kit). Insulin resistance was measured by using the formula of Homeostasis Model Assessment-Insulin Resistance: HOMA$\mathrm{IR}=$ (fasting plasma glucose $(\mathrm{mmol} / \mathrm{l}) \times$ fasting plasma insulin $(\mu \mathrm{lU} / \mathrm{ml}) / 22.5$ (Value $>2.5$ was considered as evidence of insulin resistance).

Statistical Package for the Social Sciences (SPSS) Windows, version-17 was applied to analyze the collected data. Descriptive data was described as mean and standard (mean $\pm S D$ ). Correlation analysis of serum uric acid with the various components of MetS was done using Spearman correlation method ( $p$-value $<0.05$ was considered to indicate statistical significance).

\section{RESULTS}

Among the MetS patients, male; female ratio was (56\%:44\%). Out of subjects who were taken as control, ratio was (52\%:48\%). Most of the MetS group were those of having impaired fasting glucose (IFT) and only a few included suffered impaired glucose tolerance (IGT). MetS patients were obese (increased BMI, WC and WHR), insulin resistant-measured by HOMA-IR (raised fasting plasma glucose and insulin) and dyslipidemia (raised levels of serum TG, decreased levels of plasma HDL-c). Serum uric acid levels were raised in metabolic syndrome patients as compared to controls (cases $=6.1 \pm 1.3 \mathrm{mg} / \mathrm{dL}$ : $3.6 \pm 1.2$; $p<0.001)$. 
As shown in Table which summarized the correlation between uric acid with MetS components. Uric acid showed a statistically significant positive correlation with waist circumference and serum triglyceride. Fasting plasma glucose also exhibit positive association with uric acid (statistically significant but not as strong showed by $\mathrm{TG}$ and WC). Negative correlation had been found between plasma high-density lipoprotein-cholesterol and uric acid levels.

\begin{tabular}{|l|c|c|}
\hline \multicolumn{1}{|c|}{$\begin{array}{c}\text { Component of } \\
\text { Metabolic Syndrome }\end{array}$} & $\begin{array}{c}\text { Pearson } \\
\text { Coefficient (r) }\end{array}$ & P-Value \\
\hline $\begin{array}{l}\text { Serum Triglyceride } \\
\text { (TG, unit: mmol/l) }\end{array}$ & 0.341 & 0.000 \\
\hline $\begin{array}{l}\text { Plasma High density } \\
\text { lipoprotein cholesterol } \\
\text { (HDL-c, unit: mmol/I) }\end{array}$ & -0.173 & $<0.001$ \\
\hline $\begin{array}{l}\text { Waist circumference } \\
\text { (WC, unit: cm) }\end{array}$ & 0.250 & 0.000 \\
\hline $\begin{array}{l}\text { Fasting plasma } \\
\text { Glucose (mmol/I) }\end{array}$ & 0.085 & 0.029 \\
\hline $\begin{array}{l}\text { Table-I. Pearson Correlation coefficient (r) of serum } \\
\text { uric acid with various components of Metabolic } \\
\text { syndrome }\end{array}$ \\
\hline
\end{tabular}

\section{DISCUSSION}

In this study, raised serum uric acid levels were observed in metabolic syndrome patients in addition to other biochemical abnormalities like insulin resistance and atherogenic dyslipidemia. These results are in compatible with various epidemiologic cross-sectional studies showing raised uric acid in Metabolic syndrome patients. ${ }^{13,14}$ Previous studies based on the serum antioxidant capacity of uric acid, suggested that the raised uric acid in metabolic syndrome might be the defensive reaction of body to protect the $\mathrm{RBC}$ membranes against the increased oxidative stress. ${ }^{15,16}$ Hyperuricemia not only act as a separate determinant of MetS but also act as a risk factor for atherosclerosis and CV events. ${ }^{17}$ Studies have established an association between hyperuricemia with metabolic syndrome ${ }^{18,19}$ and found $30 \%$ to $41 \%$ prevalence of metabolic syndrome in patients suffering from gout. ${ }^{20}$
This study also explored the association between hyperuricemia and various components of metabolic syndrome. It has been suggested that hyperuricemia is a risk factor for cardiovascular heart diseases as it causes abdominal obesity, dyslipidemia, raised blood pressure and plasma glucose, which are also components of metabolic syndrome. ${ }^{21}$ In our study, the data result showed a strong correlation between hyperuricemia and serum triglyceride. Several other studies supported this association too. ${ }^{22,23}$ Raised levels of both serum uric acid and triglyceride are linked to the development of Mets, numerous studies gave the explanation that as glycolysis is controlled by insulin, so uric acid might show some link to glycolysis too. ${ }^{24,25}$

This study also established a strong positive association between uric acid and waist circumference. Studies doneinthepastsupportthis association and documented that obese subjects with raised $\mathrm{BMI}$ showed raised uric acid levels in addition to classical manifestations of metabolic syndrome. ${ }^{2}$ Underlying pathophysiology might be renal damage leading to renin-angiotensin and glomerular dysfunction that occur due to certain adipocytokines secreted by adipose tissues. ${ }^{26,27}$ Moreover, some studies suggest that obstruction in synthesis and excretion of urate protein might be the main reason of raised uric acid levels in obese individuals. ${ }^{28}$ Supported by the study done on a large number of population, an inverse association had been observed between UA and HDL-c in this study. ${ }^{1}$ In another study, this inverse association was also observed and also explained that depressed HDL-cholesterol levels in MetS are due to insulin resistance which occur both in hyperuricemic and patients suffering from metabolic syndrome. ${ }^{29}$

Last association (not significantly that strong as TG, WC and HDL-c) has been established between raised uric acid and fasting plasma glucose. Study done in Japan on a large number of populations demonstrated more prevalence of type-2 DM in hyperuricemic patients. ${ }^{8}$ Insulin resistance is the hidden biochemical abnormality in both diabetic and hyperuricemia patients. ${ }^{30,31}$ Moreover, uric acid act as independent risk 
factor for developing diabetes apart from insulin resistance as supported by a 10-year follow-up study. ${ }^{32}$ Studies have been documented which did not not show any or even inverse association between uric acid and type 2 diabetes. ${ }^{33,34,35}$

\section{CONCLUSION}

Serum uric acid shows a significant correlation with components of metabolic syndrome making it a potent biomarker of diagnosing metabolic syndrome patients in coming years.

Pakistan is country of growing population with high prevalence of MetS, this new biomarker (uric acid) will not only help to sort out the high-risk asymptomatic population, but also to plan, implement and improve the preventive and treatment strategies against various cardiometabolic complications (type-2 DM, stroke and cardiovascular diseases) associated with this syndrome.

\section{Copyright@ 21 March, 2019.}

\section{REFERENCES}

1. Nieto FJ, Iribarren C, Gross MD, Comstocka GW, Cutler RG. Uric acid and serum antioxidant capacity: A reaction to atherosclerosis? Atherosclerosis. 2000; 148:131-9.

2. Bieber JD, Terkeltaub RA. Gout: On the brink of novel therapeutic options for an ancient disease. Arthritis and Rheumatism. 2004; 50(8):2400-14.

3. Rho YH, Cho SJ, Lee YH, Ji JD, Choi KM, Baik SH, et al. The prevalence of metabolic syndrome in patients with gout: A multicenter study. J Korean Med Sci. 2005; 20(6):1029-33.

4. Yoo HG, Lee SI, Chae HJ, Park SJ, Lee YC, Yoo WH. Prevalence of insulin resistance and metabolic syndrome in patients with gouty arthritis. Rheumatology International. 2011; 31(4):485-91.

5. Pacifico L, Cantisani V, Anania, e tal. Serum uric acid and its association with metabolic syndrome and carotid atherosclerosis in obese children. European Journal of Endocrinology. 2009; 160(1):45-52.

6. Grundy SM, Cleeman JI, Daniels SR, Donato KA, Eckel $\mathrm{RH}$, Franklin BA, et al. Diagnosis and management of the metabolic syndrome: An American Heart Association/National Heart, Lung, and Blood Institute Scientific Statement. Circulation. 2005; 112(17):27352752. [doi:10.1161/CIRCULATIONAHA.105.169404].
7. Quilon A, Brent L. The primary care physician's guide to inflammatory arthritis: Diagnosis. J Musculoskel Med. 2010; 27:223-231.

8. Hulsmans M, Geeraert B, DeKeyzer D. Interleukin1receptor-associated kinase-3 is a key inhibitor of inflammation in obesity and metabolic syndrome. Plos One. 2012; 7:e30414.

9. Uaratanawong $\mathrm{S}$, Suraamornkul $\mathrm{S}$, Angkeaw S, Uaratanawong R. Prevalence of hyperuricemia in Bangkok population. Clin Rheumatol. 2011; 30:887893.

10. Yoo TW, Sung KC, Shin HS, Kim BJ, Kim BS, Kang $\mathrm{JH}$, et al. Relationship between serum uric acid concentration and insulin resistance and metabolic syndrome. Circ J. 2005; 69(8):928-933. [doi:10.1253/ circj.69.928].

11. Islam M. Obesity: An epidemic of the $21^{\text {st }}$ century. $J$ Pak Med Assoc Mar. 2005; 55(3):118-22.

12. Yadav A, Jyoti $P$, Jain SK, Bhattacharjee J. Correlation of adiponectin and leptin with Insulin Resistance: A pilot study in healthy North Indian Population. Ind J Clin Biochem. 2011; 26(2): 193-196.

13. Nestel P, Lyu R, Low LP, Sheu WH, Nitiyanant W, Saito I, et al. Metabolic syndrome: Recent prevalence in East and Southeast Asian population. Asia Pac J Clin Nutr. 2007; 16(2):362-367.

14. Serpa Neto A, Rossi FM, Valle LG, Teixeira GK, Rossi M. Relation of uric acid with components of metabolic syndrome before and after roux-en-y gastric bypass in morbidly obese subject. Arq Bras Endocrinol Metabol. 2011; 55(1):38-45.

15. Cavagioni LC, Bensenõr IM, Halpern A, Pierin AM. Metabolic Syndrome in professional truck drivers who work on Highway BR-116 within the area of São Paulo City - Régis Bittencourt. Arq Bras Endocrinol Metab, Portuguese. 2008; 52(6):1015-23.

16. Krishnan E, Sokolove J. Uric acid in heart disease: A new C-reactive protein? Curr Opin Rheumatol. 2011; 23(2):174-7.

17. Glantzounis JK, Tsimoyiannis EC, Kappas AM, Galaris DA. Uric acid and oxidative stress. Current Pharmaceutical Design. 2005; 11 (32):4145-4151.

18. de Oliveira EP, Moreto F, Silveira LV, Burini RC. Dietary, anthropometric, and biochemical determinants of uric acid in free-living adults. Nutr J. 2013; 12:11. 
19. Lee WY, Park JS, Noh SY, Rhee EJ, Kim SW, Zimmet PZ. Prevalence of the metabolic syndrome among 40698 Korean metropolitan subjects. Diabetes Res Clin Pract. 2004; 65:143-9.

20. Lin SD, Tsai DH, Hsu SR. Association between serum uric acid level and components of the metabolic syndrome. J Chin Med Assoc. 2006; 69:512-516.

21. Nakagawa T, Hu H, Zharikov S, Tuttle KR, Short RA, Glushakova $O$, et al. A causal role for uric acid in fructose-induced metabolic syndrome. Am J Physiol Renal Physiol. 2006; 290(3): F625-F631. [doi:10.1152/ ajprenal. 00140.2005].

22. Gandotra $P$, Miller $M$. The role of triglyceride in cardiovascular risk. Curr Cardiol Rep. 2008; 10:505511.

23. Conen D, Wietlisbach V, Bovet P, Shamlaye C, Riesen W, Paccaud F, et al. Prevalence of hyperuricemia and relation of serum uric acid with cardiovascular risk factors in a developing country. BMC Public Health. 2004; 4(1):9. [doi:10.1186/1471-2458-4-9].

24. Matsuura F, Yamashita S, Nakamura T, Nishida M, Nozaki S, Funahashi T, et al. Effect of visceral fat accumulation on uric acid metabolism in male obese subjects: Visceral fat obesity is linked more closely to overproduction of uric acid than subcutaneous fat obesity. Metabolism. 1998; 47(8):929-33. [doi:10.1016/ S0026- 0495(98)90346-8].

25. Clausen JO, Borch-Johnsen K, Ibsen H, Pedersen $O$. Analysis of the relationship between fasting serum uric acid and the insulin sensitivity index in a population-based sample of $\mathbf{3 8 0}$ young healthy Caucasians. Eur J Endocrinol. 1998; 138(1):63-9.

26. Gagliardi AC, Miname MH, Santos RD. Uric acid: A marker of increased cardiovascular risk. Atherosclerosis. 2009; 202(1):11-7.
27. Tuttle KR. Renal manifestations of the metabolic syndrome. Nephrol Dial Transplant. 2005; 20:861-4.

28. Indraratna PL, Williams KM, Graham GG, Day RO. Hyperuricemia, cardiovascular disease, and the metabolic syndrome. J Rheumatol. 2009; 36:2842-3.

29. Marasini B, Massarotti M. What rheumatologists should know about gout and cardiovascular disease. J Rheumatol. 2009; 36:854-5.

30. Schmidt MI, Watson RL, Duncan BB, Metcalf P, Brancati FL, Sharrett AR, et al. Clustering of dyslipidemia, hyperuricemia, diabetes, and hypertension and its association with fasting insulin and central and overall obesity in a general population. Atherosclerosis Risk in Communities Study Investigators. Metabolism. 1996; 45(6):699-706.

31. Nakanishi N, Okamoto M, Yoshida H, Matsuo Y, Suzuki K, Tatara K. Serum uric acid and risk for development of hypertension and impaired fasting glucose or type II diabetes in Japanese male office workers. Eur J Epidemiol. 2003; 18(6):523-530. [doi:10.1023/ A:1024600905574].

32. Kramer CK, M"uhlen Dvon, Jassal SK, Barrett Connor E. Serum uric acid levels improve prediction of incident type 2 diabetes in individuals with impaired fasting glucose: the RanchoBernardo Study. Diabetes Care. 2009; 32(7):1272-1273.

33. Dehghan A, van Hoek M, Sijbrands EJ. High serum uric acid as a novel risk factor for type 2 diabetes. Diabetes Care. 2008; 31:361-362.

34. Taniguchi $\mathrm{Y}$, Hayashi T, Tsumura K. Serum uric acid and the risk for hypertension and Type 2 diabetes in Japanese men: The Osaka Health Survey. J Hypertens. 2001; 19:1209-1215.

35. Herman JB, Medalie JH, Goldbourt U. Diabetes, prediabetes and uricaemia. Diabetologia. 1976; 12:4752.

\begin{tabular}{|c|c|c|c|}
\hline \multicolumn{3}{|c}{ AUTHORSHIP AND CONTRIBUTION DECLARATION } \\
\hline Sr. \# & Author(s) Full Name & \multicolumn{1}{|c|}{ Contribution to the paper } & Author(s) Signature \\
\hline 1 & Shameela Majeed & $\begin{array}{l}\text { Main idea, research of previous } \\
\text { work, generating and structuring } \\
\text { article content, lead sampling and } \\
\text { laboratory analysis. } \\
\text { Supervision, guidance for the } \\
\text { article, arrange funding of this } \\
\text { research project. }\end{array}$ \\
\hline
\end{tabular}

